\title{
Material Culture and its Functional Importance to the Gogo Community in Tanzania in East Africa
}

\author{
Sadasivuni. Krishna Rao \\ E.L. Temu \\ Department of History \\ University of Dodoma \\ Tanzania (East Africa)
}

\begin{abstract}
Gogo/Wagogo, a Bantu speaking ethnic group in Dodoma region of Central Tanzania had long been identified as traditional hunter-gatherers prior to their occupation as pastoralists and agriculturists. Nowadays they are also employed in producing drought resistant crops such as sorghum, millet and corn. Our study of the Gogo material culture, their manufacturing techniques and the raw materials they used, revealed the socio-economic and technological dynamics of the community. Our ethnographic survey in the Ntyuka, Makulu and Ng'ong'ona villages has established several facts relating to the Gogo lifestyle which is similar to that of the ancient pastoral Neolithic culture which includes use of earthen handmade pottery, calabashes, wooden furniture, agricultural implements, hunting tools like bow and arrow, skin hides and beehives; drums for entertainment during festival; beads, animal feathers, leg bells, etc constitute decorative ornaments. Other household objects comprise of wooden pestle and pounder, and grindstone and stone pounder. It is interesting to note that the Gogo have vast indigenous medicinal knowledge to cure several diseases. The functional importance of their material culture becomes the significant part of the Gogo life system that needs to be preserved.
\end{abstract}

Keywords: Gogo cultural material collections, subsistence technology, equipment and their importance in survival.

\section{Introduction}

Background history: Initially small-scale subsistence economies derived from hunting gathering and pastoralism, which were alternative efforts of survival long before the advent of agricultural economy of the food producing societies. Our earliest ancestors practised scavenging besides food collection from forests and woodlands before they started hunting (Binford 1986). Even these humans in Early Paleolithic times seem to have collected seafood, eggs, nuts and fruits besides scavenging. They might have used carcasses of animals that had either been killed by predators or that had died of natural factors. According to the 'endurance running hypothesis', long-distance running as in persistence hunting, a method still practised by some hunter-gatherer groups in modern times, was likely the driving evolutionary force leading to the evolution of certain human characteristics. This hypothesis does not necessarily contradict the scavenging hypothesis, but might explain that both of these subsistence strategies either alternatively or simultaneously could have been in use sequentially. Around 1.8.ma, Homo erectus presumed to have begun subsistence strategy, which continued till later replaced by Homo sapiens around 0.2.ma. Such mode of subsistence further continued until the end of the Mesolithic period, some 10,000 years ago, although this was replaced slowly with the spread of the Neolithic revolution.

In the process of the selection of specialized hunting-gathering mode of subsistence, particularly during transition between the Middle and Upper Paleolithic period, some 80,000 to 70,000 years ago, the work also involved creating specialized tools like fishing nets and hooks and bone harpoons. Further transition into the subsequent Neolithic Period is defined by the development of nascent agricultural practices. Agriculture originated and spread in several different areas including the Middle East, Mesoamerica and the Andes beginning as early as 12,000 years ago. The Bantu speaking Gogo of Central Tanzania are observed to have practised agriculture besides continuing pastoral and small hunting-gathering frequencies. The changing life style of this community under pressures of varying physical and climatic conditions since the time of their hunting-gathering subsistence level is mostly substantiated by their material culture and their functional importance.

So, a hunter-gatherer or forager by nature depends on wild plants and animals in contrast to agricultural societies who rely mainly on domesticated species (Marlowe 2005). 
The Cambridge Encylopaedia of hunter-gatherers says, "Hunting and gathering was humanity's first most successful adaptation, occupying at least $90 \%$ of human history until 12,000 years ago when all humans lived this way" (Lee and Daly 1999). Following the invention of agriculture, farming or pastoralist groups in most parts of the world have displaced hunter-gatherers. Only a few contemporary societies are classified as hunting-gatherers, and many of them supplement, sometimes extensively, their foraging activity with farming and / or keeping animals.

\section{Statement of the Problem:}

In the changing conditions of the Gogo living standards, their social traditions, economic activities and material culture and technology, in relation to their continuous interaction with nature for nurture still have a prominent place in the country's heritage and pride. Though the community competes for higher pursuits of economic endurance nowadays by adopting agriculture, their previous pastoral and hunting-gathering activities for subsistence and survival have lot of significance in their day-to-day living system. The indigenous technology and the related equipment and household furniture reveal abundandly the pride and integrity of the Gogo. The functional importance of their material culture and technology need to be discussed to develop our knowledge on one hand, and preserving the treasures of heritage and pride on the other.

Objectives: The following are the objectives of the study;

1. To collect the Gogo material equipment and other household objects of subsistence and survival.

2. To record the raw materials used and manufacturing technology involved in the agro-pastoral and huntinggathering economies.

3. To make efforts for community involvement in dissemination and preservation of culture.

Materials and Methods: In this mission of the Gogo cultural material collection, various academic exercises at various levels were undertaken. It started with the collection of literature and theoretical approaches of anthropological thought. In the second phase, field visits to the Gogo villages to observe and collect information through ethnographic participant observation and interviews were conducted. Simultaneously, cultural materials used in foraging and agricultural activities and also household objects were collected and inventories made. Finally, technical information and raw material acquisition data along with illustrations were gathered. Various technical devices such as GPS, tapes, video camera, tape recorder, etc were used to facilitate data collection.

Significance of the Study: Primarily the Gogo culture and their material collection signify tradition, pride and integrity of the community. Their indigenousness and socio-cultural systems as reflected by changing economic patterns are the foundation for the development of unity in diversity. The interaction with nature for subsistence and protection of natural resources for recycling the economic pursuits are seen reflected in the strength of their material production. The study therefore signifies the necessity of preservation of such a heritage to direct as a polestar to the present and future generations. Further, the ideology of establishing the Village Museum of the Gogo material culture collection would offer similar scope to other communities of Tanzania in order to enhance our knowledge, research and heritage.

Theoretical approach: Few approaches seem to be appropriate to apply to the Gogo material and non-material possessions in order to understand their living systems, ideologies and adaptations. Franz Boasian Historical Particularism and Marvin Harris's Cultural Materialism are dealt with here in this context. Historical Particularism (CA 1900 - 1940) says that each culture has its own distinctive ways of thinking and acting which can only be explained by its unique past (Peoples and Bailey 1997: 66). It is imperative that each culture has historically been influenced by its past and each culture has its own unique past as the foraging subsistence activities and the associated material culture including pottery making of the Gogo recall the pastoral Neolithic way of life of the ancient time.

Marvin Harris (1979), a Cultural Anthropologist who was influenced by Marx and Malthus introduced this theory of Cultural Materialism in a new direction. He claimed that his universal theoretical strategy has equal relevance to hunting and gathering, industrial, or even hyper industrial societies. He applied his theoretical perspective to the traditional societies of hunter-gatherers, horticulturists and pastoralists. Cultural Materialism, according to Harris, is a research strategy uniquely suited to explore short-term socio-cultural stability and change, and / or the long-term social evolutionary process itself. He claims that human mind is formed by challenges presented by environment and these challenges will always shape human behavior and thought. Actually the theory of Cultural Materialism is based on two assumptions, which are macro-social theory and environment on which the foundation of socio cultural system lies. In the former, when one aspect of the socio-cultural system changes, it often has effect on many other parts of the system. In the second assumption human beings, like all life forms, must take energy from their environment for survival, and so, all life including human life, must, therefore, be lived within the constraints (like continued availability of natural resources and the tolerance of the environment including people for pollution) of their immediate environment. 
Hence, according to Cultural Materialism, all human societies are patterned along similar lines. Based on the physical environment, all components of socio-cultural systems can be organized into infrastructure, structure and superstructure. Firstly, the material infrastructure consists of the technology and social practices by which a society fits into its environment through manipulation of resources required for survival. Secondly, the structure, which are the organized patterns of social life are carried out among the members of society. Finally the superstructure consists of symbolic processes for human health and happiness.

A society's infrastructure is the primary cause of stability and change in its structure, and the structure, in turn, is the primary cause of stability and change in its superstructure. Through the Principle of Infrastructural Determinism, Cultural Materialism provides a logical set of research priorities for the study of socio-cultural life, in which, while the infrastructure is considered to be of primary importance, the structure and superstructure are not mere reflections of infrastructural processes, but are interactions with the infrastructure.

It is thus imperative that such material things as natural resources and technology mostly influence the cultural systems. Material conditions determine human thought process and de-emphasize the role of ideas and values. The theory views that the material constraints are the primary factors of cultural variations. Gogo life ways, with different levels of transition, proceed under similar line of influence of interaction between nature and nurture.

\section{Analysis and Discussion:}

African continent is an epitome of distinctive natural, biological and cultural resources. While the natural phenomenon persisted by its wide varieties of ecological diversities with environment as main component of ecosystem, the indigenous communities, with their independent cultural developments, stand for unity in diversity. Tanzania in Africa itself is a complex of different landscapes characterizing varied ecological regions extending from Mara wet lands and Serengeti plains in the north and Mbeya in the southern highlands. On the other hand, the landscape also extends from Bagamoyo and other coastal districts on the east and the Great Rift Valley on the west.

Such variant landscape environments have provided different resource hives to various communities since the time of Homo erectus, the earliest Man. There is plenty of archaeological and paleontological evidence in support of the above. It includes famous Stone Age sites of Olduvai Gorge, Isimila rock art sites, Iron Age sites and Bagamoyo and Caravan serai Swahili settlement sites, to quote a few. In many cases, some of the cultural traits of remote antiquity are found reflected in the material culture and survival techniques of the present indigenous communities. Most popular among such indigenous communities that seemingly have ancient links are the Chagga, in the north, Maasai and Gogo in the central lands of Tanganyika.

The Gogo, a Bantu speaking ethnic group is said to have established its base around thirteenth century. They are also known as Wagogo. It is a patrilineal group, which has traced its descent and inheritance through the male line. There are about 85 patrilineal clans and 53 sub-clans as estimated by the Gogo of Ugogo area who share the culture of Cigogo (Rigby 1969:66). They speak Kiswahili although their mother tongue is cigogo. Gogo clans are exogamous and so marriage within the same clan is a taboo. They practice monogamy although polygamy is highly valued and given priority. Gogo had long been identified as traditional hunter-gatherers prior to their occupation as pastoralists and agriculturalists. Mnyampala identified that the coming of Bantu-speaking agriculturalists marks the beginning of the Gogo (Rigby 1969:12).

Today, they depend on pastoral economy and they practice agriculture to some extent. Unevenly distributed rainfall, frequent floods and famine might have led them to be nomadic and made them adopt pastoral economy at the beginning. Being mobile, they move with their cattle to different landscapes in search of grazing pastures. Cattle play a dominant role in Gogo Social structure. They pay cattle as bride-price in marriage. Except in ceremonies cattle are not slaughtered for consumption. Nowadays they also cultivate drought resistant agricultural crops such as sorghum, millet and corn. Gogo are observed to share material culture and several methods of adapting to their harsh environments with the Nilotic, Barabaig and Maasai communities (http://www.britanica.com/EB checked/topic/237137/ Gogo).

There is no centralized political structure among the Gogo, although colonial administration introduced centralized authority, which was also revoked after Tanzania gained independence. That is why the Gogo are free to move to other places with their cattle herds. They comprise $31 \%$ of the total population of Tanzania. They are spread in different localities of Tanzania including Dodoma. The authors surveyed Ng'ong'ona, Ntyuka and Makulu villages around the University of Dodoma Campus (36 N 081267, E 9310568) for related field work. Gogo settlement is a typical stone house with rectangular structure called tembe. It can accommodate all family members, parents and children. Children after marriage leave parents household in order to start a separate independent nuclear family. 
Generally the stone-wall of the settlement is plastered with mud. Mud bricks and cement bricks are also used nowadays. Windows are arranged at all the sides of the wall for lighting and watching the cattle against other wild animals. The tembe normally has three rooms / partitions that are used as drawing room, sleeping room and store-room respectively. The drawing room is also used for dining although food is prepared at the entrance. Pottery, agriculture implements, grains and fire-wood etc are stored in the store room.

A few wooden beams from outside the settlement wall support the roof of the settlement. Strong wood is used to protect from insects. Usually wooden piles from mukambala, mtunduru and mhefu trees are used in the house construction. The roof is constructed by arranging sizable wooden beams side by side in a row. They are tied with a rope to keep the beams in firm position. On the top, the branches of plants, leaves and grass are spread all over the corners. Then it is plastered with mud. Above this layer small stone boulders are spread all over to prevent the roof from being damaged by wind and rain.

While the above description reveals the general scenario of the Gogo settlements, the material culture and technology they involve for their routine subsistence and survival is very interesting. They have varieties of tools, which they prepare with their own indigenous skills and techniques, according to the demands of their routine life activities. Various implements and household objects are made from different raw materials such as clay, wood, stone, skin, bone and metal. The typical Gogo furniture include hunting tools, baskets for food collection, pastoralists stick for cattle herds, storage clay pottery, kitchen ware, agricultural implements, entertainment drums and aesthetics and ornamental decorative objects. A lot of manufacturing technology is involved in producing these objects, which reflect Prehistoric Pastoral Neolithic culture of Tanzania. Surprisingly, stone circles as memorial monuments are found in the Gogo burial ground, reminding us of the continuing ancient megalithic cultural tradition. Apart from such technical skills, the Gogo possess indigenous medical Knowledge and practice for caring different diseases such as stomachache, malaria, cough and cuts. These are the precious items of Gogo heritage that deserves to be preserved for all generations.

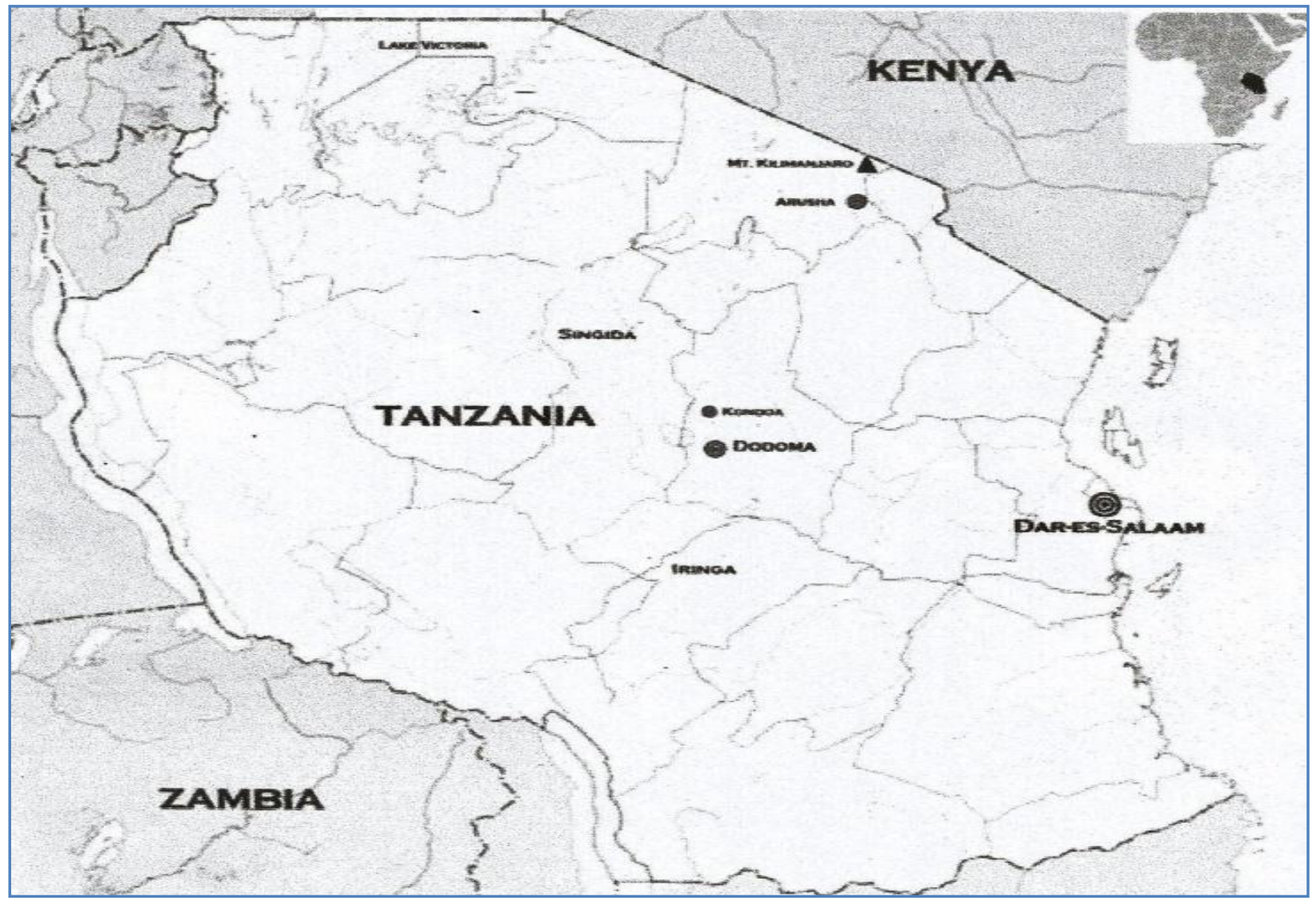

Fig. 1: Map of Tanzania 


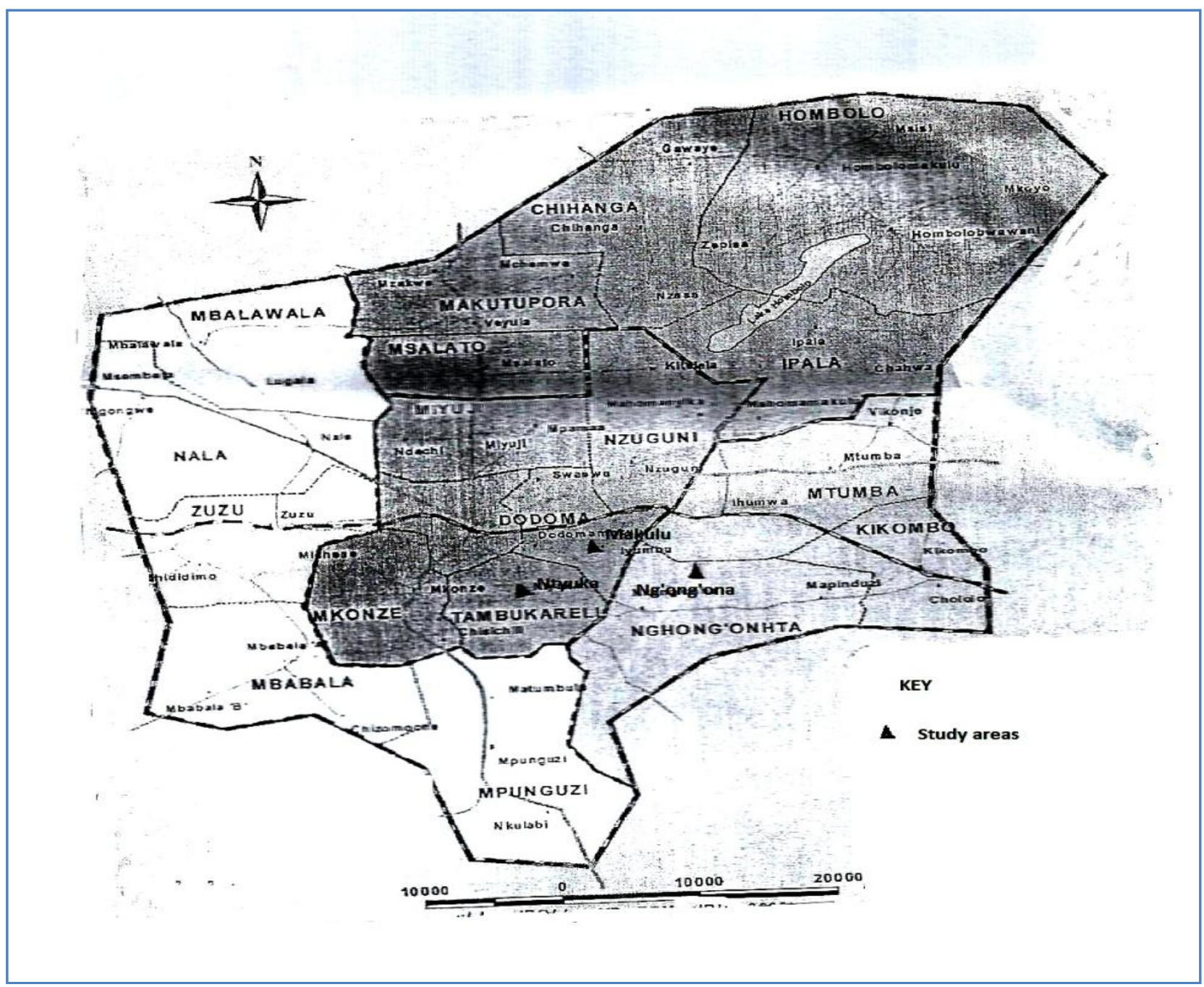

\section{Gogo material culture and their functions:}

The Gogo furniture and their functional importance for both single and multiple activities will add to our knowledge which is essential to qualify Gogo Village Museum as a home of inclusive heritage. The following is the description of each category of activities and associated tools along with their manufacturing techniques.

\section{Hunting activity:}

The Gogo respondents in the Ntyuka village explained that they go for hunting once a week to the nearby forest adjacent to the foothill, which is about a kilometer away from their settlement. They use weapons like spear and bow and arrow for hunting. They go mostly at nighttime. Hunting the wild animals supplement their subsistence. Until 1970s, the hunting practice was active and after that it has become seasonal because of gradual shifting of wild animals to other forests due to the expansion of Dodoma town and settlements and also because of unseasonal monsoon. Yet some families hunt small animals such as Phillips dik dik, antelopes, bush pig, warthog, monkey, Guinea fouls (Kanga) , -wildhare, etc. by using weapons like bow and arrow, spear, shield, stick and stones. The Gogo also use different kinds of traps to trick such animals like bush pig, warthog, monkey and guinea fouls that depend on agricultural crops and causing damage. The following are some examples of the kinds of traps.

\section{Pit Trap (Mhangwa) (Fig. 3):}

This kind of trap is prepared by inserting pointed wooden pegs in a dugout Pit of the dimensions of length, width and depth of about 2x1x1 m. respectively. Actually the pointed pegs, which are preferably made out of a hard tree locally called Mtunduru, are inserted on the ground in zigzag pattern. The pointed tip-heads are kept projected about $0.5 \mathrm{~m}$. then the grass and above it the soil are spread on the top of the trench carefully to hide the trap from the animal vision. Even the soil that was scooped out normally will also be removed from the spot of the trap. 
In the late evening they prepare such traps. When an animal walks on top of the pit the grass and soil fall down along with the animal, and the peg-points injure the body severely to suffer it to remain there. After seeing the animal being trapped people reach the spot in the early morning to collect it. An imaginary figure is illuatrated below.:

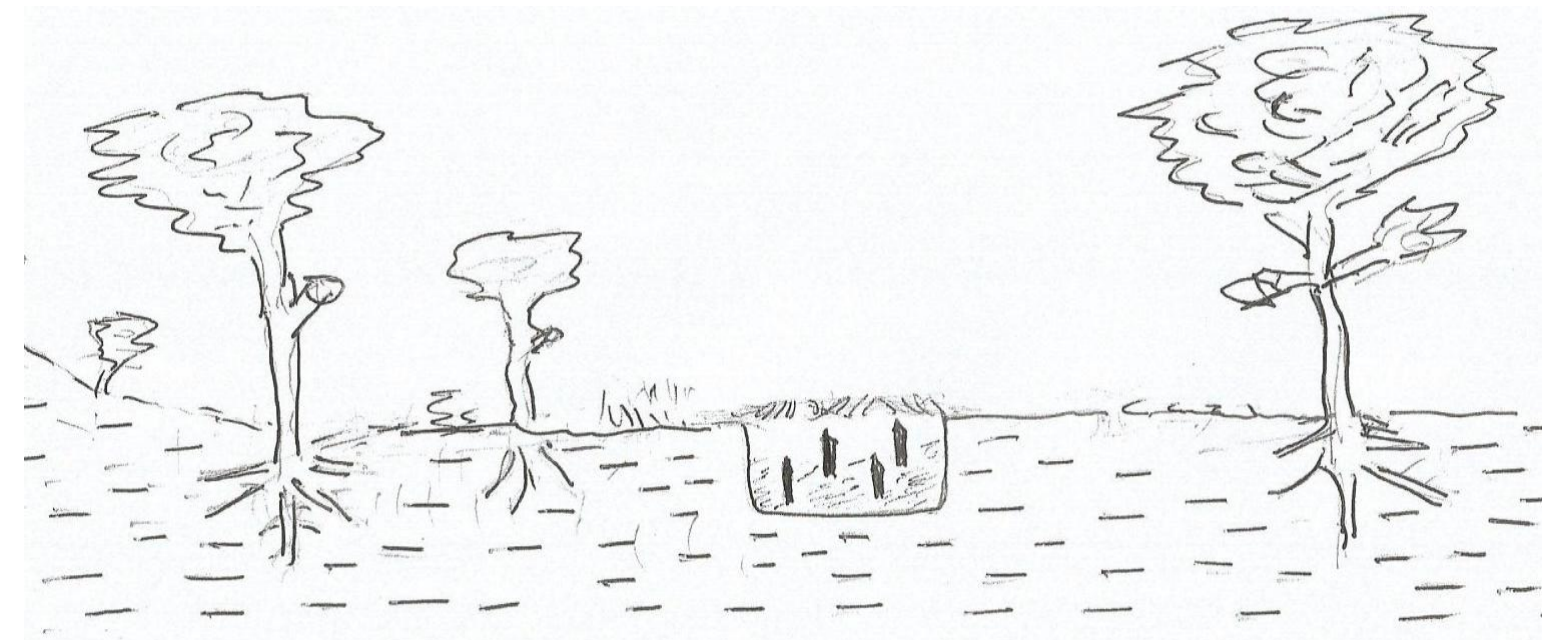

Figure 3: A pit with length, width and depth of about $2 \times 1 \times 1.5 \mathrm{~m}$ respectively is dug out. Then the pegs with sharp edge are inserted inside the pit. The height of the peg is about $1 \mathrm{~m}$.

\section{Wooden enclosure Trap, Ihutula (Fig. 4):}

In this kind of trap sizable wooden poles are erected on the surface and prepare an enclosure with an entrance. Inside the trap, some food material as bait will be placed on the top of the grass. When the animal attempts to eat the bait, the entrance gate that was attached to the bait will automatically be closed, and thereby the animal is trapped inside the enclosure. The entry inside is extended in each side of the fence that leads the animal into the enclosure, which finally traps the animal.

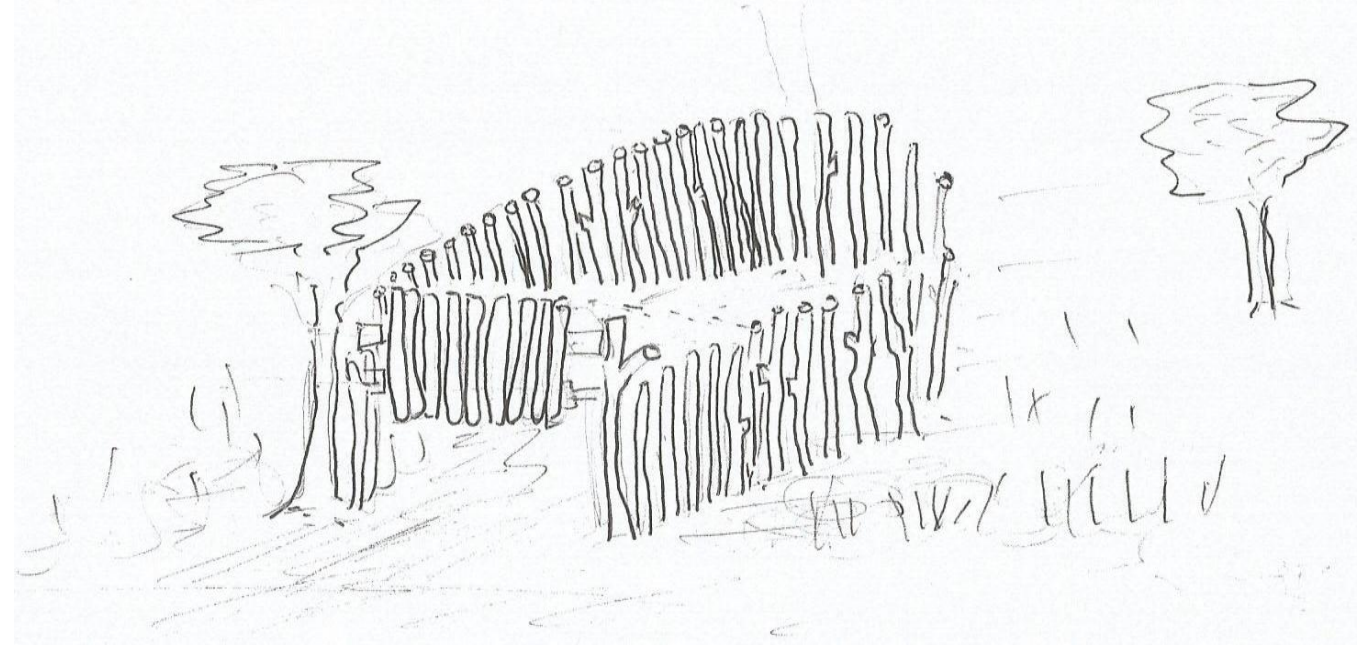

Figure 4: Ihutula trap made like a room with a door attached. Inside the room the bait is placed on the surface. Once the animal enters the room will automatically trigger the door to close.

There is also another type of Ihutula (Fig. 5) arranged with bow and arrow. In this type of trap, a portion of cropping farm is prepared with surrounding thorny fence. On one side of its entrance, pegs are firmly fixed on the ground and on the pole; a bow with an arrow is set up. The arrow is fixed with a small stopper (trigger) in order to keep the bow in the standby position. This trigger is connected by a thread that runs to the other side of the entrance in such a way that any animal entering the farm by touching the thread will trigger the bow to shoot an arrow into its body eventually.

Usually poison is applied to the arrow tip, which affects the animal very fast. Bow and arrow is made out of split wooden sticks. A string made out of the skin of cow's tail ties the ends of the stick. The skin is tightly tied until the 
stick gets bow shape (curve). The length of the bow and width at the centre are $14 \mathrm{~cm}$ and $12 \mathrm{~cm}$ respectively. The arrow, which is also made out of wood with an iron tip, has the length of about $64 \mathrm{~cm}$.

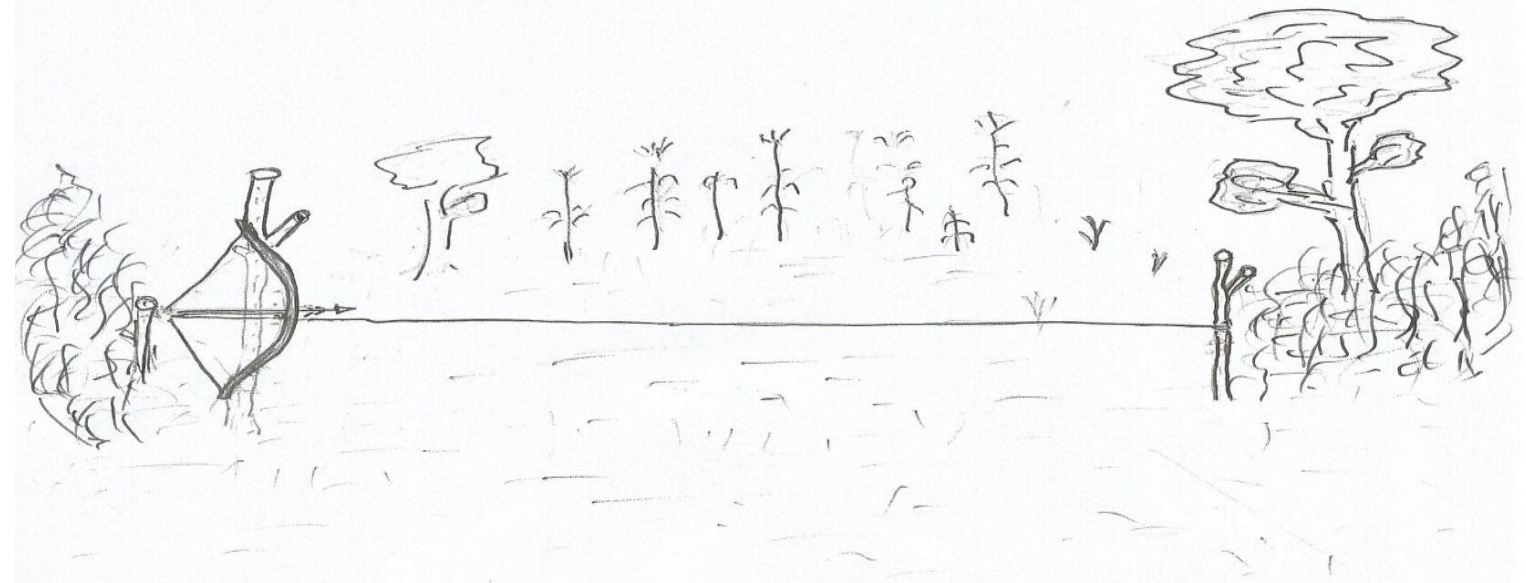

Figure 5: This kind of trap made by using bow and arrows. Several bows and arrows can be set at the entrance of a crop-containing fenced farm. The height of the arrow is set in accordance with the height of the animal aimed. Types of animals visiting the area can be identified by looking at their footprints.

\section{Noose Trap (Chidoga):}

This trap is prepared with the thread extracted from the bark of the Bao bao tree. The noose is set near the water source, which is the main passage of animals. Since there are several pegs with nooses are set to increase the probability of the trapping, the animal that is trapped initially by a single noose gradually tighten its position to severely. More the times the animal attempts to escape the more number of nooses that are associated fix more organs of the body to more severity.

4. Net Trap (Wavu) (Fig. 6): It is a hand woven net, which cannot allow small animals to pass but the head enters the net. The animal will be trapped while the hunter chases the animal to the direction of the net.

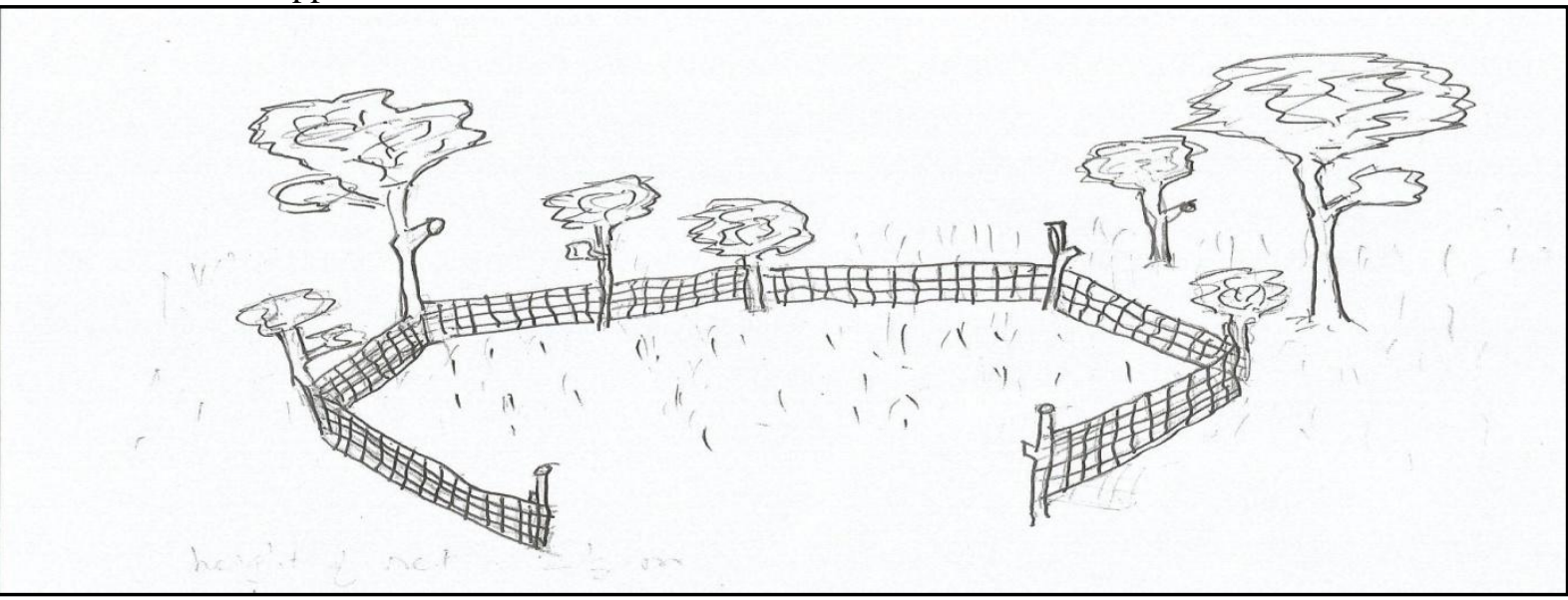

Figure 6: A net with the height of $2.5 \mathrm{~m}$ is spread to make a half circle with the entrance of about $10 \mathrm{~m}$. A group of people will chase the animals towards the direction of the net. Other persons will stand near the entrance on both sides and make the animals to enter the net where they will be trapped.

5. Spear (Mkuki): The total length of a spear is $110 \mathrm{~cm}$. The hallow iron tip which is inserted into the smooth wooden stick has the length approximately one third of the total length of the spear.

Gathering: Gogo people collect various items of different plants. Women and sometimes men join the gathering activities. There are various plants and trees from which leaves, fruits, flowers and roots are gathered. Some are consumed after cooking and some items are eaten raw. The different species include Tinhi, Ndafula, yagayaga, 
Chiwandagulu, chidingulilo (alovera), mginanandala and nhongo (see Table). They take with them the bags made out of bamboo and other creeper plants. They collect honey from the comb developed in the huge hive ( mzinga) which is a long wooden hollow log with a small hole on top of it. This hole is an entry to the bees to preserve inside the hollow space the honey gathered from flowers.

\section{Agricultural objects}

Apart from traditional hunting-gathering activity and later pastoral economy, they have developed agriculture recently. They raise maize, sorghum, groundnut and vegetables like beans, tomatoes and other leafy vegetables. They use various agricultural implements like machele (mundu/hengo) for slashing or cutting, iron knife (Nzoholo) for harvesting and carving wooden handles, iron blade attached to long wooden hand hoe (Jembe) for tilling the soil in farming, wooden hoe (total wooden) for farming and adze (Tezo an iron blade is set in a long wooden handle) for preparation of smooth handles and other agricultural implements. The measurements are mentioned in the table-1.

Objects related to Pastoralism: Cattle stick, Bow and arrow for hunting the game for subsistence and shoulder pole for carrying culinary loads etc.

Medicinal Kit: Earlier, the Gogo community traditionally had good knowledge and practice of medicine. Yet few continue to practice it today to some extent by extracting medicine from various plants available in their environment to heal some of the prevalent diseases. Some plant species are identified to extract its essence from the leaves of plants, roots and barks. For example some of the roots such as Mkambaku are used for sexual power and stomach pain while the muwelewele is used to cure constipation. Also another root type Mtarawanda is used to cure fever and malaria while mbilinyisi mixed with mnyinga is used to cure venereal diseases. This knowledge was not open to the Gogo society because only some families are specialized in medicine which they inherit it from their grandparents. Although the conventional medical services are now accessible in the Villages of Ngo'ng'ona, Makulu and Ntyuka, still people make use of the traditional medicine to cure some diseases.

Household Objects: Gogo have household furniture on wood, calabash and clay. Small stools or benches, pounder and pestle etc are made on wood. Vegetable pounders are used to pound the vegetables groundnuts and cereals. Gourds are converted into containers that are sometimes decorated with colorful designs. These containers are used to fetch water, millets, foodstuffs like ugali etc. Also they are used to drink water. Normally long necked calabash is preferred for preserving milk and traditional beer. There are pottery types made out of clay. These are cooking pots, storage pottery, pots for drinking water religious and burial pottery. The pottery is handmade (see photos). There are pots for cooking meat, vegetables, making ugali and other stew. There are also ladle, winnower, sweeper and skin mattress.. Other furniture includes musical instruments such as drums and metal flute. Wood and leather are used in drum preparation. Some of the specimen examples are shown in the table. Pottery making in the Ntyuka village (See photos in Pages 1516) is illustrated below. 


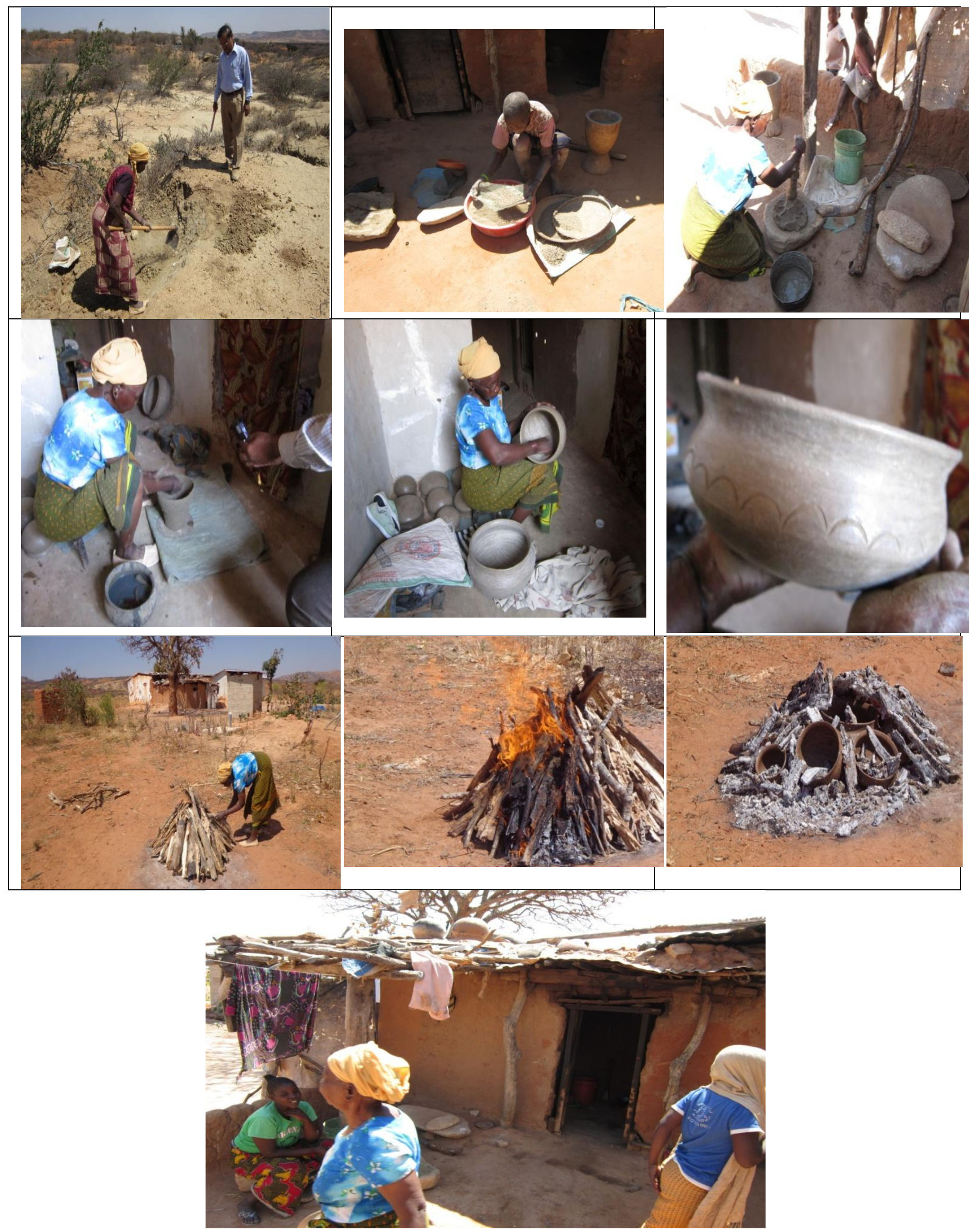


Photo-1 (Pages 16-17): Various stages of pottery making in Ntyuka village from the stage of raw material collection up to burnt pottery presented in left to right sequence.

\section{GOGO CULTURAL MATERIAL (Table-1: 4 Items):}

1.HUNTING OBJECTS

\begin{tabular}{|l|l|l|l|l|l|l|l|}
\hline S/NO & $\begin{array}{l}\text { OBJECT } \\
\text { NAME }\end{array}$ & $\begin{array}{l}\text { SWAHILI/ } \\
\text { VERNACULAR } \\
\text { NAME }\end{array}$ & CONDITION & $\begin{array}{l}\text { DIMENSIONS } \\
\text { (Length-L, } \\
\text { Width-W, } \\
\text { Height-H) }\end{array}$ & MATERIAL & FUNCTION & REMARKS \\
\hline 1 & $\begin{array}{l}\text { Bow and } \\
\text { arrows } \\
\text { (E.026) }\end{array}$ & $\begin{array}{l}\text { Upinde, Mshale } \\
\text { (upinde, songa) }\end{array}$ & Good & $\begin{array}{l}\text { Bow (124cm x 14 } \\
\text { cm Arrow (L 64) }\end{array}$ & $\begin{array}{l}\text { Wood,skin } \\
\text { (cow tail), } \\
\text { Nylon, iron }\end{array}$ & $\begin{array}{l}\text { Hunting } \\
\text { animals }\end{array}$ \\
\hline 2 & Spear & Mkuki (Mgoha) & Fair & $\begin{array}{l}\text { Total L- 110 cm , } \\
\text { L 76.5 (wood) }\end{array}$ & Wood and iron Hunting & Hall \\
\hline
\end{tabular}

3. AGRICULTURAL OBJECTS

\begin{tabular}{|c|c|c|c|c|c|c|c|}
\hline S/NO & $\begin{array}{l}\text { OBJECT } \\
\text { NAME }\end{array}$ & $\begin{array}{l}\text { SWAHILI/ } \\
\text { VERNACULAR } \\
\text { NAME }\end{array}$ & CONDITION & DIMENSIONS & MATERIAL & FUNCTION & $\begin{array}{l}\text { REMARK } \\
\text { S }\end{array}$ \\
\hline 1 & Machete & Mundu (hengo) & Fair & $\begin{array}{l}\text { Total L- } 65 \mathrm{~cm} \\
\text { L } 49 \mathrm{~cm} \text { Handle }\end{array}$ & Wood, iron & Slashing, cutting & \\
\hline 2 & Knife & $\begin{array}{l}\text { Kisu cha mtama } \\
\text { (nzohoro) }\end{array}$ & Good & $\mathrm{L} 20.5 \mathrm{cn}, \mathrm{W} 3 \mathrm{~cm}$ & iron & $\begin{array}{l}\text { Harvesting } \\
\text { sorghum, carving } \\
\text { wooden handles }\end{array}$ & \\
\hline 3 & Hand hoe & $\begin{array}{l}\text { Jembe, mpini } \\
\text { (isili/chaka) }\end{array}$ & Fair & $\begin{array}{l}\text { Blade L } 24 \mathrm{~cm} \mathrm{x} \\
\text { w25 } \\
\text { Handle L } 97 \mathrm{~cm} \text {, } \\
\text { W } 3.5 \mathrm{~cm}\end{array}$ & $\begin{array}{l}\text { Wood(Mgiha } \\
\text { ) Iron }\end{array}$ & Farming & \\
\hline 4 & $\begin{array}{l}\text { Wooden } \\
\text { hoe }\end{array}$ & Jembe (isili) & bad & $\begin{array}{l}\text { Blade- } \text { L34cm, W } \\
17 \mathrm{~cm} . \quad \text { Handle } \\
\text { L83cm, W } 6 \mathrm{~cm}\end{array}$ & wood & farming & \\
\hline 5 & Adze & Tezo (Mbazo) & Good & $\begin{array}{l}\text { Blade L16.5cm, } \\
\text { W } 5.5 \mathrm{~cm} \text {. Handle } \\
\text { L } 47 \mathrm{~cm} \text {, Dia (D) } \\
4.5 \mathrm{~cm}\end{array}$ & $\begin{array}{l}\text { Iron, wood } \\
\text { (Mgiha) }\end{array}$ & $\begin{array}{l}\text { Carving- bee hive, } \\
\text { handle, stools etc. }\end{array}$ & \\
\hline 6 & Bee hive & Mzinga (msiku) & bad & & $\begin{array}{l}\begin{array}{l}\text { Wood } \\
\text { (mheme) }\end{array} \\
\end{array}$ & Bee keeping & \\
\hline
\end{tabular}

\section{HOUSEHOLD OBJECTS}

5.

\begin{tabular}{|c|c|c|c|c|c|c|c|}
\hline S/NO & OBJECT NAME & $\begin{array}{l}\text { SWAHILI/ } \\
\text { VERNACULAR } \\
\text { NAME }\end{array}$ & CONDITION & DIMENSIONS & MATERIAL & FUNCTION & REMARKS \\
\hline 1 & Stool (E.018) & Kigoda (igoda) & Fair & $\mathrm{H} 20 \mathrm{~cm}, \mathrm{D} 27 \mathrm{~cm}$ & wood & $\begin{array}{l}\text { Sitting } \\
\text { Game }\end{array}$ & \\
\hline 3 & $\begin{array}{l}\text { Mortar } / \text { Pounder } \\
\text { and pestle }\end{array}$ & $\begin{array}{l}\text { Kinu } / \text { Mchi } \\
\text { (ituli/mtwango) }\end{array}$ & Fair & $\begin{array}{l}\text { H } 28 \mathrm{~cm}, \text { D } 17 \mathrm{~cm} \\
\text { Peastle L } 56 \mathrm{~cm} \text {, } \\
\text { W5 cm }\end{array}$ & $\begin{array}{l}\text { Wood } \\
\text { (mdachi), } \\
\text { Pestle (mgiha) }\end{array}$ & $\begin{array}{l}\text { Pounding }- \\
\text { vegetable, ground } \\
\text { nuts, etc }\end{array}$ & \\
\hline 4 & $\begin{array}{l}\text { Mortar } / \text { Pounder } \\
\text { (E.040) }\end{array}$ & Kinu (ituli) & Fair & $\begin{array}{l}\mathrm{H} 45 \mathrm{~cm}, \mathrm{D} 27 \mathrm{~cm} \\
\text { (top) }\end{array}$ & $\begin{array}{l}\text { Wood } \\
\text { (mnyinga) }\end{array}$ & $\begin{array}{l}\text { Pounding } \quad- \\
\text { cereals }\end{array}$ & $\begin{array}{l}\text { Not allows to } \\
\text { sit on }\end{array}$ \\
\hline 5 & Container (E.006) & $\begin{array}{l}\text { Kibuyu } \\
\text { (Ntungu) }\end{array}$ & good & $\begin{array}{l}\mathrm{H} 36 \mathrm{~cm}, \mathrm{D} 23 \mathrm{~cm} \\
\text { (center) }\end{array}$ & calabash & Fetching water & \\
\hline 6 & Container (E.012) & Kipeyo (lupeyo) & Good & $\begin{array}{l}\text { W } 23 \mathrm{~cm} \text { Longest } \\
\text { part } \\
\text { D } 12 \mathrm{~cm}\end{array}$ & Calabash & $\begin{array}{l}\text { For drinking } \\
\text { water, alcohol, } \\
\text { milk, milking }\end{array}$ & \\
\hline 8 & $\begin{array}{l}\text { Container } \\
(300 \mathrm{ml})\end{array}$ & Kipeyo (upeyo) & Good & $\mathrm{W} 12 \mathrm{~cm}, \mathrm{H} 6 \mathrm{~cm}$ & Calabash & $\begin{array}{l}\text { For children } \\
\text { drinking water, } \\
\text { milk or medicine }\end{array}$ & \\
\hline
\end{tabular}




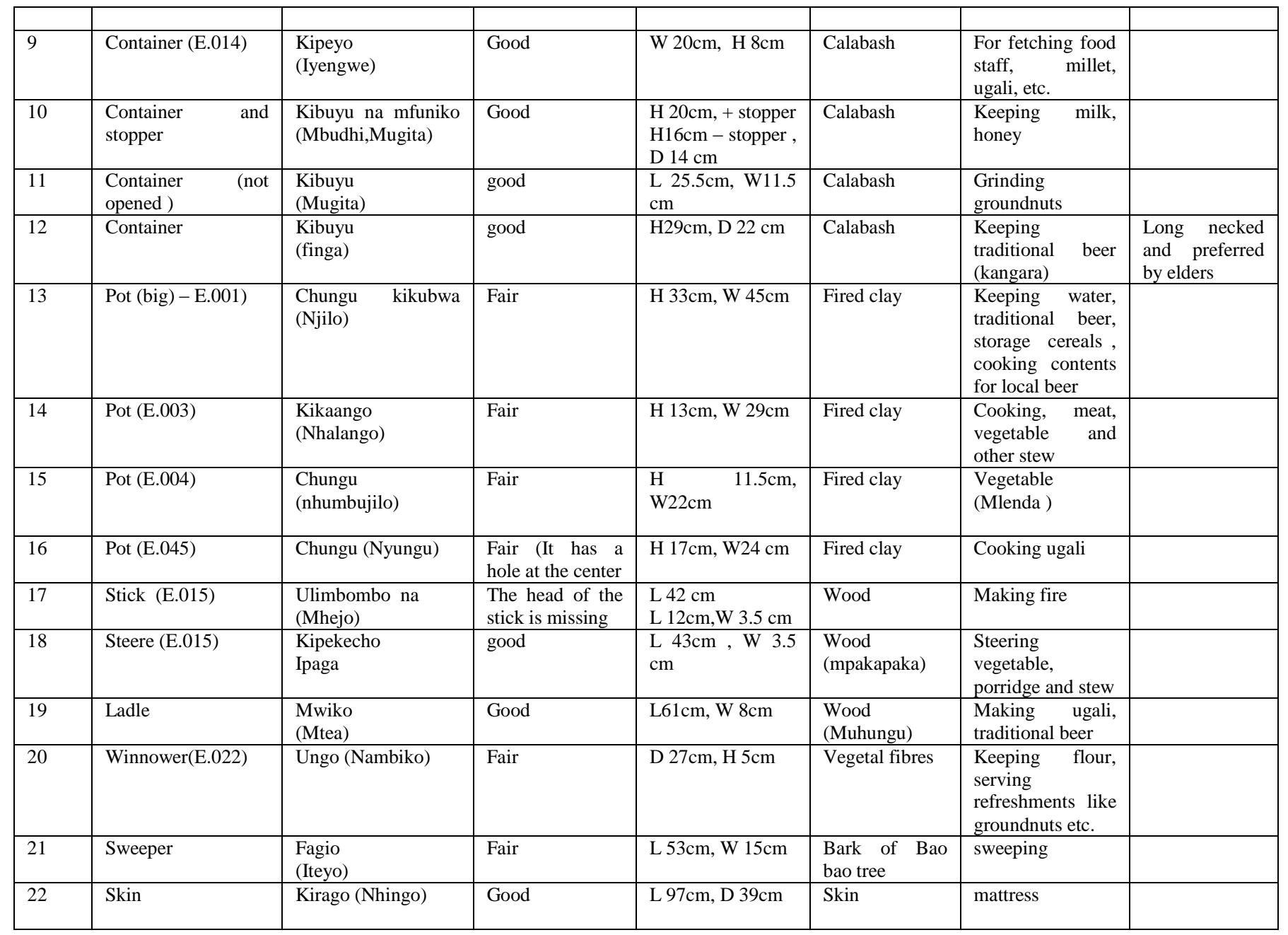

\section{Musical Instruments}

\begin{tabular}{|c|c|c|c|c|c|c|c|}
\hline S/NO & $\begin{array}{l}\text { OBJECT } \\
\text { NAME }\end{array}$ & $\begin{array}{l}\text { SWAHILI/ } \\
\text { VERNACUL } \\
\text { AR NAME }\end{array}$ & $\begin{array}{l}\text { CONDITIO } \\
\mathbf{N}\end{array}$ & $\begin{array}{l}\text { DIMENSIO } \\
\text { NS }\end{array}$ & $\begin{array}{l}\text { MATERI } \\
\text { AL }\end{array}$ & FUNCTION & $\begin{array}{l}\text { REMAR } \\
\text { KS }\end{array}$ \\
\hline 23 & Drum & Ngoma & Fair & $\begin{array}{l}\mathrm{H} \\
\text { D } 40 \mathrm{~cm} \text { (top) }\end{array}$ & $\begin{array}{l}\text { Leather/ } \\
\text { goat skin }\end{array}$ & $\begin{array}{l}\text { Musical } \\
\text { drumming }\end{array}$ & \\
\hline 24 & flute & Filimbi/ & good & $\begin{array}{l}\mathrm{L} 6 \mathrm{~cm}, \mathrm{w} 1.5 \\
\mathrm{~cm}\end{array}$ & Metal & Musical songs & \\
\hline
\end{tabular}




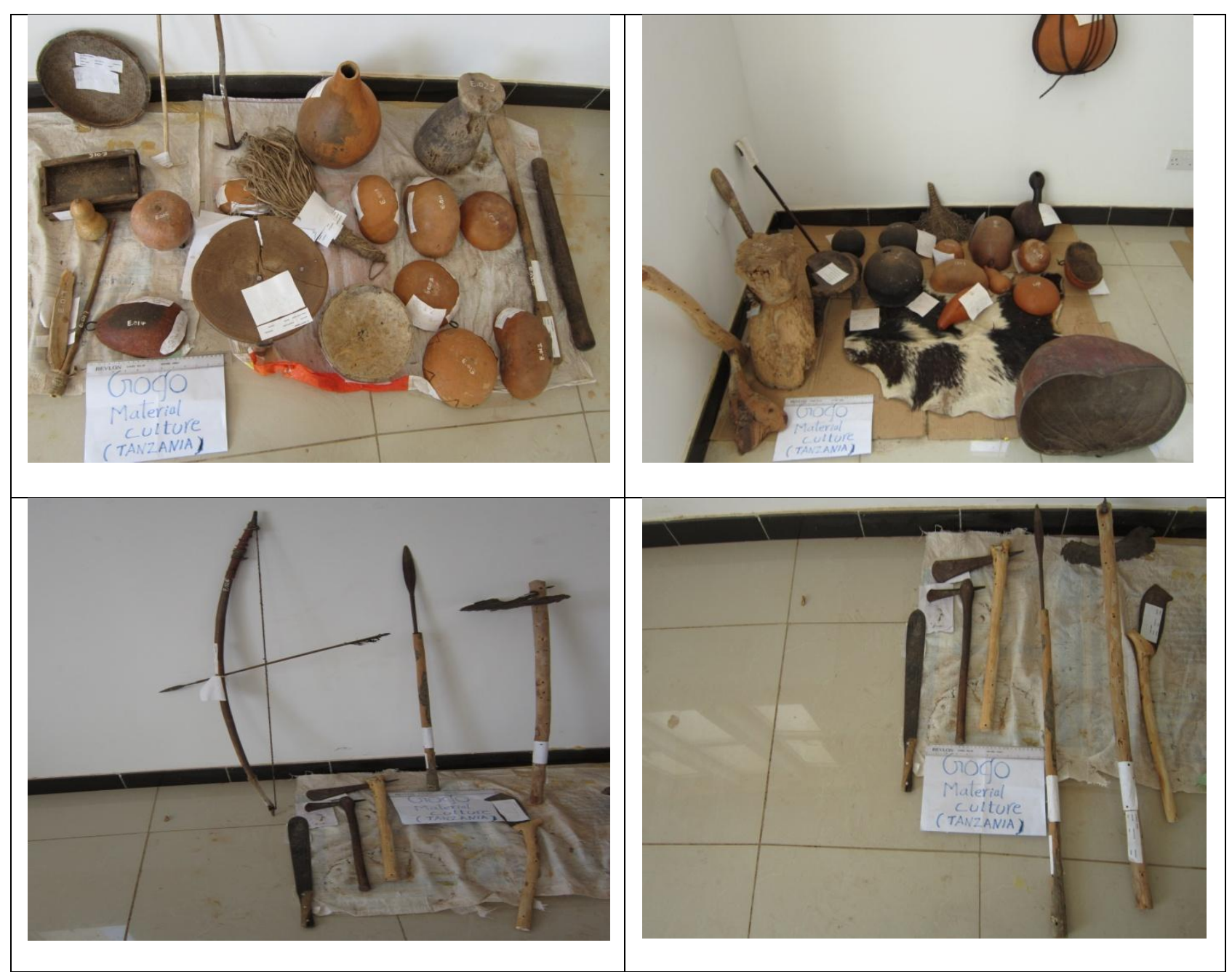

Photo-2 : Dept. Collections: Gogo Household objects, Hunting and Agricultural implements)

Interpretation and Conclusion: The above description of a selective set of specimens is a small store of Gogo functional heritage. Lot of materials is being produced and used in this manner. It is like environment-to-environment cycle. What they produce from their local environment will be used to exploit the same environment for their subsistence. The furniture or the material culture that they produce from the raw material procured from the environment manifests this concept. Such products of natural environment are wooden furniture, hunting implements, gathering containers, agricultural tools, household objects, musical instruments like drums and flute - the list is incomplete

Gogo material culture reflects the functional utility in the socio-economic and religious activities of subsistence and survival. What one can observe in the production and usage of various materials, containers and techniques is that the people in their struggle for survival in the inevitable cultural transition from one economic stage to another as a result of the influence of environmental and other internal factors have procured different raw materials available in the surrounding environments in order to prepare related techniques and strategies of subsistence. Although the community tends to change from indigenous hunting-gathering way of life to pastoralist and agricultural subsistence, they continue it to supplement the subsistence as buffer.

The techniques of material production, which are adopted, have effective results as evident from their complex techniques of trapping of animals. The agricultural implements such as digging stick, knife etc have added to the potential utility in the cultivation of various crops such as maize, sorghum, millet and vegetables like tomato, beans etc. The other containers, storage pots have added more to their household furniture. Particularly the handmade pottery of the Gogo reflects the pastoral Neolithic pottery with various forms of utility, colors and designs. Actually few Neolithic pottery bearing archaeological sites were identified around the University of Dodoma Campus (Krishnarao 2017).

Conclusively, the ethnographic description of the Bantu speaking Gogo has lot of significance in the continuing traditions of socio-cultural and economic systems. The slight variations within the systems are accountable as the 
reflections of infrastructural situations. Cultural variations as reflected in the economic determinants of changing environments are quite normal under the effect of the principle of infrastructural determinism. Such variations occur very slowly because of the resistance given by the opposite force accumulated in the original traditional system of the Gogo. The changing environmental conditions such as drought, urban expansion etc forced the Gogo to gradually focus more on agriculture although they continue to survive on pastoralism and some hunting-gathering activity. Interestingly, the indigenous technology, equipment and other household objects of various socio-cultural and economic activities signify maximum utilization of available natural resources in the manufacture of those products or required materials. Changes in the levels of subsistence influence on the other parts of the socio-cultural systems for new adjustments as is explained by the Marvin's cultural materialism.

On the whole, the indigenousness and the life ways of the Gogo heritage collection deserves to be protected and preserved as a museum of material culture. Under the active initiation and encouragement of the University of Dodoma (UDOM), the authors, at the concerned department have applied for a UNESCO project for grant in order to establish the Gogo Museum for cultural Development. This will facilitate research activity, propagate the pride of the community and promote public realization and national integrity.

\section{Acknowledgment}

The authors are very grateful to the Ntyuka villagers for their elaborate narration of various subsistence strategies. Especially they are thankful to Mrs. Rose Mary for her hands-on explanation of pottery making techniques. Finally the University of Dodoma deserves appreciation for its extension of moral support to the researchers.

\section{References}

Krishna Rao, S. (2018). 'Archaeology and heritage around the University of Dodoma Campus in Tanzania'. Journal of African Interdisciplinary Studies (JAIS), 2(11), 16-35. ISSN 2523-6725 (On line), Nairobi (Kenya).

Lee, R.B. and Daly, R.H. (1999). Cambridge Encyclopaedia of Hunters and Gatherers., Cambridge University Press.

Marlowe, F.W. (2005). "Hunter-gatherers and human evolution". Evolutionary Anthropology: issues, News and Reviews 14 (2): 54-67.

Marwin, Harris. (1979). Cultural Materialism: The struggle for a Science of Culture., Random House, The University of California, USA.

Rigby, Peter. (1969). Cattle and Kinship among the Gogo: A Semi Pastoral Society of Central Tanzania., Cornell University Press, London. 